This is the accepted version of the following article: GONZÁLEZ REYERO, S., 2012: "Under divine wings: Forms of territorial and ideological domination during the Iberian Iron Age", Oxford Journal of Archaeology, vol. 31, no 3, 261-281 https://doi.org/10.1111/j.14680092.2012.00389.x which has been published in final form at https://onlinelibrary.wiley.com/doi/abs/10.1111/j.1468-0092.2012.00389.x This article may be used for non-commercial purposes in accordance with the Wiley Self-Archiving Policy [http://www.wileyauthors.com/self-archiving].

\title{
UNDER DIVINE WINGS: FORMS OF IDEOLOGICAL AND TERRITORIAL DOMINATION DURING THE IBERIAN IRON AGE
}

\author{
Susana González Reyero ${ }^{1}$
}

\section{Summary}

This article explores the ways in which the Iberian communities of the Iron Age developed a model of extension and legitimization of their social hierarchies. By analysing the testimonies of the ideational realm and the territorial occupation of the Iberian populations, I am able to determine how the representation of a winged goddess is used by certain families to legitimize the control and possession of the natural resources. Thus, the contextual analysis of this goddess can explain a territorial domination established in the southern sub-plateau of the Iberian Peninsula. A Mediterranean model of the goddess is transformed by combining traditional and foreign elements to create an original and unique synthesis. What draws our attention, though, is how this new being is eventually integrated into the changes that took place in local populations, which established new constructions of space and new social patronage relationships. New practices appear, such as the persistence of ancient forms of pottery and a symbolic opposition to imported objects. In the following pages, I will identify the underlying process as a territorial vertebration conducted by some settlements as they explored a broader spatial control. I will explore

\footnotetext{
${ }^{1}$ E-mail: susana.gonzalezreyero@cchs.csic.es. Spanish National Research Council (CSIC).
} 
one of these territories and the ideology employed to implement this form of domination.

\section{INTRODUCTION. THE HETEROGENEOUS SOCIAL COMPLEXITY OF THE IBERIANS}

During the Iron Age, the Mediterranean coast and southern part of the Iberian Peninsula are identified with the Iberians (Ruiz, Molinos, 1999) (Fig. 1). Their origination and specificity are seen today as part of a long process in which their social dynamics, original and heterogeneous, are built in a context of extensive cultural contact, which I primarily conceive as multidirectional, asymmetrical and transforming (Gosden, 2008; Delgado, Ferrer 2007; Cañete, Vives 2011). The vast geography of the Iberian world appears, therefore, as a multilingual mosaic. This variety is fundamental for understanding the varied responses to the contact with foreign populations of diverse origins.

Throughout the extensive period between the sixth century BC and the Roman conquest, the Iberian people transform their way of exercising, legitimising and subjugating to power. In some territories, archaeology has detected various practices of social hierarchy and how a stratified and aristocratic society is built, based on fictitious parental ties. The territory studied here leads us to the processes of consolidation of the aristocracies and the progressive development of clienteles.

The discovery of Pozo Moro (Albacete) in the early 1970's transformed the study of Iberian funerary record (Fig. 2). Numerous studies have analysed this complex monument as an early form of aristocratic power ${ }^{2}$. The idea of Pozo Moro as a unicum is still predominant and widely accepted. Given this fact, I will argue that Pozo Moro acquires new meaning through its integration in the archaeological record, which illustrate the spatial expression of a model established in the southern sub-plateau of the Iberian peninsula. Integrated,

\footnotetext{
2 There is a vast bibliography regarding Pozo Moro, for instance, Almagro Gorbea (1978; 1982; 1983; Olmos (1996), Alcalá Zamora (2002); Prieto (2002); López-Pardo (2006), García Cardiel (2009).
} 
therefore, into a political project which sought to legitimise the appropriation of a territory.

In this sense, the characteristics shared in this territory, which I will detail below, were likely the result of an active transformation intended to encourage the self-identification as a group, which differed from their neighbours (Jones 1997, XIII). Thus, it encouraged the development of an identity, which acquires great importance in emerging forms of power, as well as the intent to impose the ideological norms of a minority over society at large. The creation of a shared identity is a critical and powerful force of social cohesion, which increases hierarchical power within social relationships (Herring 2000,46).

SHAPING THE EARLY DISCOURSES OF POWER: A GODDESS OF NATURE IN POZO MORO AND CERRO GIL

The vast visibility of Pozo Moro in the landscape must have helped to achieve one of the main objectives of those who had erected it: the attempt to legitimize the power of a lineage by the remembrance of the actions of a man. The primary purpose of being visible probably explains its exact location: Pozo Moro is not located near a settlement. On the contrary, the construction marks an important crossroads, which may indicate the desire to be seen and to symbolically appropriate a larger territory.

It is widely recognized that Pozo Moro materializes an unprecedented ideological agenda, in the forms it takes and the territory where it is located. Several arguments support this interpretation, such as its own architectonic and iconic entity, its position in the landscape and its related grave goods. The proposed chronology, based on these grave goods, can be traced to the second half of the sixth century BC (Almagro-Gorbea 2009). The studies that have been carried out will allow me to dwell on some aspects of the reliefs (Fig. 3). This set has been partially preserved but manages to uphold the origin of a dynasty through the deeds and merits of a man. The myth exposed in this monument becomes the foundation of the present (Olmos 1996, 104). The achievements sanctioned by the deity, which 
legitimize the social standing of the aristocratic family, are carefully detailed.

The reliefs on the west and north sides of Pozo Moro ${ }^{3}$ represent two closely related scenes. In the north, a man carries a branch, heavily laden with fruits and birds, while the west side shows a winged representation with hathoric hair, sitting on a folding chair looking directly ahead with her arms and legs spread open. Her wings emphasize her hybrid, supernatural nature. She is not alone; two birds are symmetrically aligned on her shoulders. She also holds a plant in each hand, displaying her relation to nature. The plants sprout as well under her feet. In fact, she is a dynamic figure, which brings forth nature with her birth. This Pozo Moro relief has been defined as the likely representation of the epiphany or the appearance of a deity (Olmos 1996).

In fact, this hybrid figure appears again in the necropolis of Cerro Gil, Iniesta (Cuenca). It is part of a burial mound that would have a certain visibility in the funerary space. I will argue how there could have been a connection between the locations of both representations, which are separated by about $60 \mathrm{~km}$. (Fig. 4).

Cerro Gil is located in the region of La Manchuela (Cuenca), in an area where the elevated area of Mirabueno provides moderate elevation above the extensive surrounding plains (Fig. 6). At about 200 metres from the necropolis, a four hectare settlement was surrounded by the creeks of La Junca and La Encina and some exceptionally fertile land (Fig. 5). There were several wells in the surrounding area (Fig. 7), a fact that could have determined the location of the settlement. The 39 tombs that have been excavated, dated on the fourth century BC, have allowed the grave cremations and burial mounds built of adobe and stone to be documented, with average lateral dimensions between 1.50 and 2.50 metres (Valero

\footnotetext{
${ }^{3}$ Based on the current reproduction at the National Archaeological Museum in Madrid.
} 
$2005,620)$.

Surrounding one of the largest burial mounds of this necropolis, number 1026, a mosaic was built with white, red and black pebbles. This burial mound has preserved lateral dimensions of $5 \mathrm{~m} \times 5 \mathrm{~m}$, well above the average of the rest of the burial mounds (Valero 2005, 623). Inside, an enclosure surrounded by stones was found, which contained four urns with cremated remains and grave goods. It is difficult to pinpoint the exact location of burial mound number 1026 within the necropolis, since the limits of the latter have been affected by agricultural activities.

Other burial mounds in this necropolis were also surrounded by these pebble mosaics, which were approximately $50 \mathrm{~cm}$ wide. Pebble mosaics built a perimeter of respect around certain burial mounds. Some were decorated geometrically, such as number 1008 . So these types of mosaic surroundings in Cerro Gil were a form to differentiate them from the rest. Pebble mosaics allowed, therefore, a way to represent the sense of belonging or shared traits of a particular group. This occurs as well in the representation of the goddess, who does not appear in any other support or object in the necropolis. From what we know, the only complex figuration was the one surrounding burial mound number 1026 (Fig. 8). In fact, the mosaic might have surrounded some of the other three sides. However, damage caused by agricultural tasks and illegal excavations, have hampered its preservation.

In Cerro Gil, the figure shows a winged woman, with a hathoric hairstyle, who is seated on a folding chair with her arms and wings raised (Fig. 9). She holds a plant in each hand. Two birds are symmetrically placed between the flowers and her head. She appears barefoot, screaming, with two schematic necklaces or ornaments and a round disc on her body. Several other elements surround her. To her left, a carnivore opens its jaws and sticks out its tongue and to the right another animal seems to flee. The complex representation of the latter's head could indicate that it is a hybrid being, or perhaps, two different animals. In 
any case, the representation of its hindquarters and legs leads me to believe that this is another carnivore. Given its state of conservation, little more can be said. In any case, there are two carnivores standing on opposite sides of the goddess, who emerges and screams. On the top left of the goddess, we can see possible vegetal elements. A horizontal line separates them from the animal below, perhaps an indication of different spaces. On the far right, broken lines trace and frame the representation.

Again, the emergence of the goddess implies the presence of two birds and two carnivores, and a vegetal environment which she touches and possibly brings about. It evokes as well certain sounds: the voice of the goddess, her cries and possibly the beating of her wings. All this would probably help shape her attributes, as a not fully anthropomorphic goddess linked to wild nature, its beings and sounds. It is also the divinity that is evoked before death.

The goddess with outspread wings has been linked to the model of Astarte (Marinatos 2000; Olmos, Tortosa 2010). I will now emphasize how the Hecate described in Hesiod's Theogony appears as a Pótnia Théron (Mazon 1923, 23), a great goddess of the threshold and death, with aglaá dora on land, sea, and the starry sky (Theog. 404-452) (Bermejo 2001, 17). The features shared between this archaic Pótnia Théron from Hesiod and the representation of the Iberian Peninsula confirm, once again, similar traits among some goddesses from various areas of the ancient Mediterranean. The Iberian goddess displays specific features, which are different from the Mediterranean models. Unlike the often symmetrical Mediterranean composition, Cerro Gil introduces centrifugal movement and noise. Thus, the elements taken from different areas of the Mediterranean interact in a unique way and in a distinctive syntax.

I will not focus on the current debate over the concept of hybridization to categorize these new representations of the Iberian context (Given 2004; Van Dommelen 2006, 137; 
Osborne 2008; Dietler 2009, 30), since my objective is to analyze the social relations that underlie the use and production of these objects. That is, the forms of social organization, with its different social groups - hegemonic or not - and its diachronic evolution within the Iberian territories.

The idea and form of this goddess could have reached the Iberian Peninsula through various means. Transported in small metal or ivory objects and documented in several areas in the Iberian Peninsula, the figure was transformed in Pozo Moro and Cerro Gil to a monumental scale. In this sense, it was a magnification of an image that had only been spread in the exclusive world of luxury objects of aristocracies, such as the ivory comb found in Medellín (Badajoz) and in Cortijo Colorao (Granada), the bronzes of El Berrueco (Salamanca), a pyxis in Cruz del Negro (Sevilla) or the bronze vase from Valdegamas (Badajoz) (Fig. 10), all of them dated between the seventh and sixth centuries BC. These objects were hoarded in the social milieu of the elites. When it becomes necessary and social relationships require it, the groups immortalize their new representations, making them visible in the construction of the social space.

An essential feature of this Mediterranean model is that it relates the winged goddess to the exploits of a male hero. Thus, the divine presence sanctioned actions that contributed to the legitimization of the social differentiation of a man and, by extension, of his lineage. In the case analyzed here, the local construction of the goddess seems to have been used as part of a strategy to legitimize certain Iberian aristocratic groups. So my hypothesis is that when the time came to physically represent legitimising discourses, the Iberian aristocracies took certain aspects of an ancient Mediterranean model, which they transformed and reinvented. Thus, certain epic actions, located in the mythical time of the goddess, were used as a justification of the origins of a dynasty based on the exploits of a founding hero, something that seems to infer patrilineal differentiation processes. 
POZO MORO AND CERRO GIL IN THE LANDSCAPE: DISCERNING THE TERRITORIALITY OF AN IDEOLOGICAL MODEL

Pozo Moro and Cerro Gil allow us to explore the possible materialization of an ideology and a form of domination. While the sixth century BC seems to be largely characterized in the southeast of the central Spanish plateau by a dispersed pattern of settlement, towards the end of the fifth century $\mathrm{BC}$, this situation seems to change and an increasingly intense occupation of the territory is documented, as revealed by the increasing number of settlements, most of them small and located near water sources. By the fourth century BC, we find a hierarchy of settlements, articulated from central locations (Soria 2002, 538, 569572).

Regarding Pozo Moro, no settlements from the sixth century BC have been found in its vicinity (Fig. 11). The construction remained temporarily isolated, a prominent landmark. The closest notable population centre is Saltigi (nowadays Chinchilla, Albacete). I will therefore link Pozo Moro to Chinchilla, as others authors have already done (Soria 2002, 142). In any case, Chinchilla is located about $14 \mathrm{~km}$ away, so even if it was related to Pozo Moro, this distance is too great for them to form a habitat-necropolis relationship (López Pardo 2006,25$)$. The truth is that we find a monument that is too far away from any central entity.

The location of Pozo Moro is, however, central to its interpretation. It is an argument in favour of those who doubt that the first use of the monument was funerary. The burial mound could have been installed afterwards as a part of the necropolis, when the monument was probably already in ruins ${ }^{4}$. If Pozo Moro was not a funerary space near a

\footnotetext{
${ }^{4}$ This subsequent necropolis has been linked with a small agricultural and livestock settlement (Alcalá-Zamora 2003, 217).
} 
community, we must ask ourselves why they chose this location on the plain. It could be due to a landmark built on the periphery of a territory controlled by a nearby oppidum, either Chinchilla, Cerro Fortaleza or El Amarejo (Bonete). This kind of construction on the periphery of a territory is well-known in the Iberian world, as seen in El Pajarillo (Jaén) (Molinos et al. 1998).

This area is characterized by a landscape with small hills, interspersed with plains with pools of an endorheic nature. The entire region, including both areas of Pozo Moro and Iniesta, was part of the historical region of La Mancha de Montearagón. Pozo Moro was built in this endorheic landscape. A highly visible point was chosen, marked by two fundamental characteristics. One is its proximity to a well, a permanent water source, the only one in the environment that does not dry out in summer. The control over this water source would be important in this landscape, characterized by Strabo as vast and with a limited water supply (Meana, Piñero 1992, 100). Another characteristic is that Pozo Moro is located in a slightly endorheic hollow where several routes converge (Almagro-Gorbea 1983; Blánquez 1990; Prieto 2002), in a major crossroads between the Mediterranean coast and the inner plateau. Thus, Pozo Moro was perhaps the best place to create the legitimizing message of a local power. This context gives meaning to the iconography of the man with the fertile branch, as the founder of a new territory that the presence of the winged goddess introduces at the time of the myth.

I have already mentioned the distance between Pozo Moro and Iniesta. However, they are not just geographically unconnected points with a very similar iconographic representation. I will now address how these territories were related, not only by the exceptional representation of the goddess, but based on some facts of the archaeological record and local routes that point to their connection in the Iberian period.

Firstly, the archaeological record from both areas share certain features. Regarding their 
material culture, there are common features, such as the imported pottery found in Pozo Moro and some other locations in Cuenca, such as Cabeza Moya (Alcalá-Zamora 2003, 226227; Navarro, Sandoval 1984, 264-265, figs. 29 and 49). More significant is the fact that the area of Iniesta is one of the northernmost locations with funeral rites that include the construction of burial mounds and the use of pebble mosaics, as in other necropolis in Albacete, such as El Salobral. We detect these burial mounds in centres located north of Iniesta, such as Alconchel de la Estrella, Pajaroncillo, Barchín del Hoyo or Campillo de Altobuey. The fact that they share the same funerary landscape, monumentalized by these burial mounds, is especially significant. Images and funerary architecture become a material element with enormous communicative potential, an active element in the construction of social identities (Delgado, Ferrer 2007, 23). This area of Iniesta is also linked to southern areas by the presence of south Iberian epigraphy, such as the plates of Abengibre (Albacete) and the inscriptions in Abrigo de la Reiná (Alcalá del Júcar, Valencia) (Olmos, Perea 2004). Taken together, these arguments seem to suggest that this area of Cuenca shared certain traits with the Iberian territories of the south.

Secondly, I will mention the settlements and the routes that connect them. The distribution of the settlements in the region of the Júcar and Abengibre rivers shows that the hydrographic conditions, characterized by narrow and embedded valleys, must have conditioned the displacements (Sillières 1990; Sanz 1997, 2006; Soria 2000, 478; AlcaláZamora 2003, 217).

The areas of Pozo Moro and Iniesta share, as we have seen, the representation of a goddess, certain similarities in their material culture and the existence of a necropolis with burial mounds. Both were also part of a historic area with a geographical foundation, the Mancha de Montearagón. But if we consider that some tracks appear to have structured the Iberian settlements from ancient times (Soria 2000, 565), it is essential that Chinchilla and Iniesta would have been connected by two paths: the 31 of the itinerary of Antoninus - from 
Caesaraugusta to Laminium - and the Royal cattle track from Cuenca to Cartagena (Sillières 1990; Palomero 1987, 148; Abascal 1990, 103-106; Soria 2002, 142, fig. 1; Alcalá-Zamora 2003, 230).

From the crossroads where Pozo Moro is located, what would be later known as the Royal cattle track from Cuenca to Cartagena stands out (Fig. 12) (Prieto 2000, 329). From preRoman times, it would have been the easiest natural way to access the plateau from the southeastern coast of the Iberian Peninsula, as well as a major track for the seasonal migration of herds. It was located just 700 metres east of Pozo Moro (Blánquez, 1990; Prieto 2000,333$)$. Its layout vertebrates several well-known Iberian sites, all connected to water wells (Almagro-Gorbea 1983, 181).

On the other hand, the itinerary of Antoninus describes a road, number 31, which connected Chinchilla and Iniesta (Fig. 13). From Complutum to Chinchilla, the route follows the socalled road of Cartagena (Palomero 1987, 142; Sanz 1997, 249-253). From Ad Putea in Iniesta, the route was diverted to the east along the course of the Abengibre stream. The archaeological record indicates intense trade along this pathway before the Roman conquest (Palomero 1987, 35-39), including Campanian pottery, amphorae from the first century BC and the circulation of coins (Soria 2000, 538-539).

There is yet another route that connects Pozo Moro with the area of Cuenca: the Royal cattle track of Los Serranos (Fig. 12), which connects this area of Albacete with the mountains of Cuenca, running through Iniesta and La Manchuela. After crossing the Júcar in Valdeganga, the road meets the mountain range of Montearagón, ascending through the valley of La Quebrada towards Higueruela. Slightly south, it reached several Iberian centres, such as Amarejo, the Llano de la Consolación and the Cerro de los Santos.

It is possible that the archaeological features shared by the territories of Chinchilla and Cerro Gil tell us about certain contacts and alliances, destined to control the paths of a 
territory, which would skirt the endorheic pool area and, once the Júcar river was reached, would follow the course of the Abengibre to La Manchuela. What would have motivated their interest? Among the products that could have driven this possible territorial control, its cereal abundance undoubtedly stands out, since it was the economic base of the Iberian people and its agrarian aristocracies. Esparto and hemp, both highly valued in ancient times, were key in this area ${ }^{5}$.

Among the many products that might have been exchanged there, I will also highlight salt as one of the main resources in the area of La Manchuela, which would have interested people from the south. Pliny the Elder illustrates the importance of the Roman exploitation of salt rock in Egelasta, where salt was mined in almost translucent blocks and was very appreciated, among other things, for its medicinal properties (Nat., XXXI, 80). Egelasta has been precisely identified around Iniesta, in Minglanilla, where the mansio Ad Putea XXXII on road 31 of Antonino's itinerary was located (Palomero 1987). Some authors have suggested that this exploitation began in protohistoric times (Morère 2006), in conjunction with Punic populations or the dynamics associated to the Greek trade (Rouillard 1991, 209). Excavation in Molino Sanchón II (Villafáfila, Zamora) have demonstrated that salt extraction began by the second half of the third millenium BC (Guerra-Doce et alii., 2011). In our case, I will highlight the need for salt as a food supplement for livestock, salted foods, and activities such as metallurgy, hide processing, etc. Thus, salt would have been an important resource in the area between Iniesta and Chinchilla, which can also be linked to the importance of livestock activity in the pastures of the Highlands of Albacete. We should not dismiss, therefore, that its collection and use could have been controlled by certain local groups, who exchanged it and developed social means to control it. This would have been

\footnotetext{
${ }^{5}$ The economic exploitation of esparto undoubtedly preceded the Iron Age, as shown by the remains of esparto from the Bronze Age found in El Castellón (López Precioso 1993).
} 
a significant economic reason to establish links from Chinchilla, and control the routes and settlements located north of the Júcar river.

IDEOLOGY IN THE CONSTRUCTION OF POLITICAL TERRITORIES IN THE SOUTHEASTERN PART OF THE CENTRAL SPANISH PLATEAU: LEGITIMACY AND EXTENSION OF A PATRONAGE MODEL

I will now argue that certain ideas associated with the Mediterranean model for the winged goddess were probably established in local Iberian societies, since afterwards, when it became necessary to build new models to substantiate the lineage, the figure of the winged goddess was recovered. At that point, it would have been reformulated as an amalgam of new and older elements, including its association with plants, birds, carnivores or its hybrid and winged nature. But it appeared then within constructions that fulfilled new social roles and reshaped social relationships.

Therefore, this representation in the southeast of the Iberian Peninsula transformed the mediterranean model. My hypothesis is that the goddess appeared in the local discourse following situations of social change, when Pozo Moro and Cerro Gil became spatial symbols, mirroring phenomena of undoubtedly social dimensions. At certain times, when it was socially necessary to legitimize a form of power, they would have undertaken larger innovative constructions, such as the tower of Pozo Moro and the monumentalized burial mound of Cerro Gil. Both spaces created memory in a place that lacked such references (Delgado, Ferrer 2007, 32). Beyond its greater or lesser degree of similarity to others such as the Hécate of Hesiod or the Phoenician Astarté, what interests me is how this goddess became a part of the local social relations and the creation of a history for certain lineages. Not everyone in the community had access to the ritual and the funeral space, and not all in the necropolis could, indeed, appropriate its figure. Thus, the privilege of memory, which was provided by the burial space, is limited to a few. Even more restrictive is the link to the 
goddess. What can we say about these social groups? This requires re-examining the contexts of each iconographic representation.

The case of Pozo Moro is better known and I refer to its studies for a more detailed approach (Fig. 14). The grave goods that have been associated with the monument are dated between 530 and 500 BC (Almagro-Gorbea 2009) and they consist of a few objects that are mostly sumptuous and imported: various objects of gold, silver and bronze, iron and bone, almost completely destroyed, a C-shaped attic kylix, from painter Pithos inner circle (Olmos 1996), an Athens 581 class lekythos, and the handle of an Italo-Greek or Etruscan bronze vase, depicting a naked young man carrying a branch on his shoulders, which resembles the iconography of the reliefs. Attention has been paid to the oinochoe-kylix association, related to a ritual of funeral libation (Almagro-Gorbea 1983, 184; AlcaláZamora 2003, 34).

In the case of Cerro Gil, the grave goods, as well as other crucial aspects, are only partly known. The grave goods included four Iberian urns (Fig. 8), two bronze belts, a bronze bead, two curved knives, two annular fibulae and fragments of what has been identified as a bronze cauldron (Valero 2005, 630). One of these urns, possibly the oldest, is an urn called "de orejetas", a characteristic Iberian craft usually dated from the middle of the sixth century $\mathrm{BC}$ to the fifth century $\mathrm{BC}$. The type of burial and the grave goods seem to indicate a chronology of the early fourth century BC (Valero 2005), as indicated by the annular fibulae and bronze belts, although this urn "de orejetas" could be an older object, which indicates perhaps a deliberate adherence to older forms (Hodos 2008, 276).

A number of aspects of these Cerro Gil grave goods are noteworthy. I emphasize, on the one hand, the absence of weapons. In addition, the lack of imported materials, that we find in other notable Iberian tombs, such as the one of the Dama de Baza (Granada). I stress this fact to point out how some tombs which, given their construction and associated 
elements, we can relate to an important member of the community, did not include imported objects. These members did not seem to need neither the accumulation nor the prestige usually associated to these imports.

We find in Cerro Gil objects related to various functions. On the one hand, indicators of prestige related to clothing and personal ornaments, such as fibulae, bronze belts and buttons. On the other hand, objects related to the funeral banquet and specific functions of prestige, such as the cauldron and the curved knives. In this regard, it seems that in Cerro Gil, we find a group whose social function was not based on their ability to gather materials imported from the Mediterranean. Nor are there grave goods related to war or violence. The role or social status of these individuals could have positioned them beyond the need to compete for the exchange and accumulation of imported objects, as in other contexts where the leaders claim to have a divine origin (Godelier 1996, 97).

Both Pozo Moro and Cerro Gil share certain elements that indicate a right to sacrifice. In a Pozo Moro relief, we find a sacrifice scene that involves cooking wild boar meat in a cauldron. A being with an animal head holds a knife and is ready to proceed with a sacrifice ${ }^{6}$. Other examples in the Iberian territories link these curved knives to ritual contexts, as in Archivel, Collado de los Jardines, La Luz and La Encarnación. Also, the iconographic appearance of sacrifices link curved knifes to those conducting sacrifices. An exceptional example is the "Sacrificer from Bujalamé" (Jaén) (Olmos 2001-2002), which shows a man about to sacrifice a lamb with a curved knife (Fig. 15). For this occasion, he wears a short tunic featuring an element also present in Cerro Gil: a bronze belt which could identify his

\footnotetext{
${ }^{6}$ Also in some amphorae from Etruria, daimôn with wolf heads are represented, maybe related to Apolo Timbreo, who, also wolf headed, sacrificed with the makhaira and boiled the flesh in a cauldron (Cerchiai; d'Agostino 1999, fig. 56-58, 117).
} 
lineage ${ }^{7}$. Also the paterae of Tivissa (Tarragona) represents a sacrifice, which is performed by a figure that, like the goddess discussed here, appears winged. So we have to consider that the families associated with Pozo Moro and Cerro Gil could have had the social privilege of performing certain types of sacrifices.

At a more general level, my hypothesis is that all this evidence and the similar representation of the winged goddess in Pozo Moro and Cerro Gil indicate the existence of alliances or kinship relationships between the families settled in those territories, who influenced the economic and social activities throughout the valleys and roads I have mentioned.

Against this hypothesis I propose, we could argue that simply two families shared a common belief in the same goddess. However, I believe that the analysis of images and the microspatial and territorial contexts allow me to argue that they must have had something else in common. First, due to the uniqueness of the representation. If it had been a more widespread belief, whose expression had no particular social connotations, why were there not more burial mounds or more representations? This leads me to argue that the link between the buried and the winged goddess must have belonged to a privileged few. Being able to represent her certainly must have been a restricted and infrequent privilege. A second argument is the scale. A belief can be translated perfectly into the small scale of the bronzes, ivories or other small sized items (such as the aforementioned examples from Medellín, Cortijo Colorao, etc.). In Pozo Moro and Cerro Gil, this is exceeded, there is a change, and the idea is transferred to the constructions. A new message, clearly visible to everyone, is created to influence the entire community. A third argument is the analysis of the grave goods and its social functions, including the ritual. The fourth argument leads us

\footnotetext{
${ }^{7}$ Bronze belts have been linked to the male lineage in other areas of the Iberian world, such as Cástulo (Ruiz, Molinos, 1999). In the case of Cerro Gil two types have been documented, with both closed low necklines (B3B3 type) and open low necklines (B2A1) with a chronology of V-IV centuries BC (Lorrio 1997, 219).
} 
to the territory and the relationship these areas had historically, since they were linked by the Roman road 31 of Antoninus' itinerary, which was based on previous routes and natural paths. Geography and the scarcity of water sources also limit the possible layouts of these roads.

These reasons allow me to hypothesize that the underlying process is an attempt to control a territory. It would include the communication path that left the mountains of Chinchilla to the east and crossed the Júcar river towards the north, through the Abengibre creek and the Cardeal cattle track to La Manchuela and Iniesta. Analyzing these representations and their archaeological contexts allows me to emphasize their possible relationship with the expansion processes carried out by certain oppida, in order to create some political territories. This is a process that has been identified during the fifth and fourth centuries BC, a time when sociopolitical cohesion processes among elites, as well as the geopolitical formation processes of the Iberian territories are detected (Ruiz, Molinos 1999; Ruiz et al. 2001; Grau 2010, 110). The expansion process meant new neighbourly relations between the population centres, new economic relations and an extension of the patronage model. I believe that the joint study of Pozo Moro and Cerro Gil allows us to determine some of their specific formulae.

In this regard, the consolidation and growth of certain nuclei was the one of their ruling families, imposed by the use of weapons, but also by the "acceptance" of their justificatory tales, which linked them to a divine or superhuman realm. They exercised their power through force, but its continuation was supported and legitimised through tales that could be remembered with images. Thus, their power was achieved with violence but also, fundamentally, with consent. And this consent could only be instituted if there was a set of representations and beliefs that were "shared" by the dominated and dominant families, which favoured the idea of a common "progress" (Godelier 1989, 12). 
It appears, therefore, that the large-scale representation of the goddess came at a time when the aristocracies were looking for new means of controlling a territory that surpassed the oppidum. The testimonies that I have analyzed here seem to suggest that in this wellconnected territory, these attempts to control a larger space could have actually taken place. Legitimization through religious beliefs, the connection of some aristocrats with the divine realm and their right to perform certain rituals seem to have been some of the bases of their power.

The establishment of new social models required the development of new formulae for the ideational realm (Godelier 1996). The appearance of images, new myths, etc., seem related to processes of social change (González Reyero 2010; 2011). The aim was possibly to justify coercion and a growing hierarchy, while the myth, exposed via images in the funeral landscape, would be one of the means they used. In this sense, the exploits of the Pozo Moro hero would be the starting point for the construction of a new territory.

But this ideology, even though it was created by the governing power, informs us about the general population that it sought to rule. We know that religion afforded certain individuals a special status that would help establish their supremacy over others. In the present case, the goddess appears linked to a social group that seems to assume the power to perform ritual sacrifices. Thus, this new form of power is ideologically supported by a religious explanation of why access to resources is limited to certain people. These new forms of domination would seek to establish and extend to the entire community a legitimization of inequality, a new collective identity that would be imposed over other possible previous identities, possibly less hegemonic and perhaps more silenced.

In fact, the connection of the goddess to a specific project to build a territory is supported by its subsequent absence in the archaeological record. Indeed, the goddess will not appear any more as she does in Pozo Moro and Cerro Gil, monumentalized and visible, in the vast 
Iberian archaeological record. This allows me to conclude that its meaning, while part of visible structures in the landscape, was associated with a particular form of domination of the territory, in which a myth was made real and was endowed with materiality.

A foundational and mythical history was monumentalized in order to legitimize the social hierarchization. If, as I have argued, this case represents a formula of territoriality and domination, it is possible that, by being buried in Cerro Gil, the group would conspicuously reflect its link with an ancestor or an ally coming from the south. Because, while the grave goods and their associated functions were kept out of sight inside the tomb, a clear message was exposed outside: it was the protection of the goddess that differentiated them from the rest.

The analysis I have laid out shows the ideological and territorial formulations that are behind how the social hierarchies in the Mediterranean Iron Age were constructed. Social prestige seems to have been much more complex that the often mentioned hoarding of imported products. It is therefore essential to analyze these processes from the standpoint of their constant transformation that was imposed by the instability underlying its legitimizing basis.

The Mediterranean model appears to have been only the starting point for the creation of an ideology, according to which some groups tried to become hegemonic in this territory of the Central Spanish Plateau. This meant masking or silencing other beliefs, other identities that were either not allowed or did not require an expression through images, and whose testimony we try to recover from other aspects of the archaeological record, such as the domestic space and the production activities. These allow us to deepen our knowledge of the specific formulae that tried to become hegemonic and formed the social landscapes of the Iberian Iron Age.

\section{ACKNOWLEDGEMENTS}


This essay forms part of the research project Iberian societies among the Bastetania and Contestania regions (PIE 200910I100). I would like to thank R. Olmos, C. Rueda, F.J. Sarasola and F.J. Sánchez-Palencia for their help during the preparation of this article.

Spanish National Research Council (CSIC)

Centro de Ciencias Humanas y Sociales

C/ Albasanz 26-28, E-28037 Madrid. SPAIN

E-mail: susana.gonzalezreyero@cchs.csic.es

\section{REFERENCES}

ABASCAL, J.M. 1990: Inscripciones romanas de la provincia de Albacete, Instituto de Estudios Albacetenses, Albacete.

ALCALÁ-ZAMORA, L. 2002: La necrópolis ibérica de Pozo Moro: sus fases y su cronología, II Congreso de Historia de Albacete. Arqueología y prehistoria, vol. 1, 199-202.

ALCALÁ-ZAMORA, L. 2003: La necrópolis ibérica de Pozo Moro, Real Academia de la Historia, Madrid.

ALMAGRO-GORBEA, M. 1978: Los relieves mitológicos orientalizantes de Pozo Moro, Trabajos de Prehistoria, Vol. 35, no 1, 251-278.

ALMAGRO-GORBEA, M. 1982: Pozo Moro y el influjo fenicio en el Período Orientalizante de la Península Ibérica, Rivista di Studi Fenici, 10,2, 231-272.

ALMAGRO-GORBEA, M., 1983: Pozo Moro. El monumento orientalizante, su contexto sociocultural y sus paralelos en la arquitectura funeraria ibérica, Madrider Mitteilungen, 24, 177293.

ALMAGRO-GORBEA, M., 2009: "El "kýlix" de figuras rojas arcaicas de Pozo Moro (Albacete)", Quaderns de prehistòria i arqueologia de Castelló, n 27, 2009, 63-81.

BERMEJO, J.C. 2001: Hécate y Asteria: aspectos de la concepción del espacio en el "teogonía" Hesiódica. In López Barja, P., Reboreda Murillo, S., (eds.): Fronteras e identidad en el mundo griego antiguo, III reunión de Historiadores, Santiago de Compostela, 15-28.

BLÁNQUEZ, J. 1990: La formación del mundo ibérico en el sureste de la meseta: estudio arqueológico de las necrópolis ibéricas de la provincia de Albacete, Instituto de Estudios Albacetenses, (Albacete).

BURILLO, F. 2007: Los celtiberos. Etnias y estados. 2 ed., Crítica, Barcelona.

CAÑETE, C; VIVES-FERRÁNDIZ, J. 2011: "Almost the same": dynamic domination and 
hybrid contexts in Iron Age Lixus, Larache, Marocco, in Postcolonial Archaelogies, World Archaeology, vol. 43 (1), 124-143.

CERCHIAI, L.; D'AGOSTINO, B. 1999: Il mare, la morte, l'amore. Gli Etruschi, i Greci e l'immagine (Rome).

DELGADO, A.; FERRER, M. 2007: Cultural Contacts in Colonial Settings: The Construction of New Identities in Phoenician Settlements of the Western Mediterranean, Stanford Journal of Archaeology 5: 18-42.

DIETLER, M. 2009: Colonial encounters in Iberia and the Western Mediterranean: an exploratory framework. In Colonial Encounters in Ancient Iberia: Phoenician, Greek and Indigenous Relations (eds.), M. Dietler and C. López-Ruiz. Chicago, IL: University of Chicago Press, 3-48.

GARCÍA CARDIEL, J. 2009: "Renacer entre leones: una nueva perspectiva de los leones de Pozo Moro (Chinchilla, Albacete)", in Lucentum, n 28, 51-68.

GIVEN, M. 2004: The Archaeology of the Colonized. London: Routledge.

GODELIER, M. 1989: L'idéel et le matériel: Pensée, économies, sociétés (Paris).

GODELIER, M. 1996: L'énigme du don, Fayard (Paris).

GONZÁLEZ REYERO, S. 2010: Nature and the symbolization of landscape in the Iberian iconography (III-II BC). Images and social dynamics, en Levêque, L.; Ruiz del Árbol, M.; Pop, L., (eds.) Heritage, Images, Memory of European Landscapes, 41-57, L'Harmattan, (Paris).

GONZÁLEZ REYERO, S. 2011: Plants in Eastern Iberia Iron Age: From daily work to the ideological construction of the community. In Chevalier, A.; Marinova, E.; Peña-Chocarro, L., eds., Plants and people: choices and diversity through time, forthcoming.

GONZÁLEZ REYERO, S. 2012: Plants in Eastern Iberia Iron Age: From daily work to the ideological construction of the community. In Chevalier, A.; Marinova, E.; Peña-Chocarro, L., eds., Plants and people: choices and diversity through time, forthcoming, Oxbow.

GOSDEN, C. 2008: Arqueología y colonialismo: el contacto cultural desde 5000 a.C. hasta el presente. Barcelona, Bellaterra. First Edition: Archaeology and Colonialism (Cambridge University Press, 2004).

GRAU, I. 2010: Paisajes sagrados del área central de la Contestania ibérica, Tortosa, T.; Celestino, S., (eds.); Cazorla, R. (coord.), Debate en torno a la religiosidad protohistórica, 101-122 (Madrid).

GUERRA-DOCE, E.; DELIBES DE CASTRO, G., ABARQUERO MORAS, F.J.; VAL RECIO, J.; PALOMINO LÁZARO, A. 2011: The Beaker salt production centre of Molino Sanchón II, Zamora, Spain, Antiquity, 85, no 329, 805-818.

HERRING, E. 2000: 'To see oursels as other see us!' The construction of native identitites in southern Italy. In Herring, H.; Lomas, K. (ed.) (2000): The emergence of State Identities in Italy in the first millennium BC. Accordia Specialist Studies on Italy 8, (London), 45-78.

HODOS, T. 2008: Striking a Local-Global Balance in Eastern Iberia: A Comment on VivesFerrándiz, Journal of Mediterranean Archaeology 21.2 (2008), 273-276. 
JONES, S. 1997: The Archaeology of the Ethnicity. Constructing identities in the past and in the present. Routledge, (London-New York).

LÓPEZ PARDO, F. 2006: La torre de las almas. Un recorrido por los mitos y creencias del mundo fenicio y orientalizante a través del monumento de Pozo Moro, Madrid.

LÓPEZ PRECIOSO, F.J. 1993: El poblado de El Castellón (Hellín y Albatana) y el inicio del Bronce Final en Albacete. In Blánquez, J., Sanz, R. (coords.), Arqueología en Albacete, Universidad Autónoma de Madrid, 57-84 (Madrid).

LORRIO, A. 1997: Los celtíberos, Real Academia de la Historia (Madrid).

MAZON, P. 1923: Hésiode, (Paris).

MARINATOS, N. 2000: Goddess and the Warrior: The Naked Goddess and Mistress of the Animals in Early Greek Religion, Routledge (London).

MEANA, M. J.; PIÑERO, F. 1992: Estrabón. Geografía. Libros III-IV (Madrid).

MOLINOS, M., CHAPA., T., RUIZ, A.; PEREIRA, J. 1998: El santuario heroico de El Pajarillo (Huelma, Jaén), (Jaén).

MORÈRE, N. 2006: Le sel atlantique hispanique dans I'Antiquité, in J.C. Hocquet; J.-L. Sarrazin (dir.) Le sel de la Baie. Histoire, archéologie, ethnologie des sels atlantiques, Rennes, 65-85.

NAVARRO, J. SANDOVAL, C. 1984: Cabeza Moya (Enguidanos, Cuenca). Primera y segunda campañas. Años 1980 y 1981, Noticiario Arqueológico Hispánico, nº 19, 199-270.

OLMOS, R. 1996: Pozo Moro: ensayos de lectura de un programa escultórico en el temprano Mundo Ibérico, in R. Olmos Romera (ed.) Al otro lado del espejo. Aproximación a la imagen ibérica, 99-114, Madrid.

OLMOS, R. 2001-2002: Concordia y violencia en la naturaleza ibérica: un esbozo sobre percepciones, Anales de prehistoria y arqueología, no 17-18, 2001-2002, 205-214.

OLMOS, R.; PEREA, A., 2004: La "vajilla" de plata de Abengibre, in Olmos, R; Rouillard, P., La vajilla ibérica en época helenística: (siglos IV-III al cambio de era), 63-76 (Madrid).

OLMOS, R.; TORTOSA, T. 2010: Aves, diosas y mujeres, en T. Chapa; M.I. Izquierdo, (eds.), La Dama de Baza: Un viaje femenino al más allá, 243-258, (Madrid).

OSBORNE, R. 2008: "Colonial cancer", Journal of Mediterranean Archaeology, 21(2), 2814.

PALOMERO, S., 1987: Las vías romanas en la provincia de Cuenca (Cuenca).

PRIETO, I.M. 2000: El recorrido en torno a la sepultura turriforme de Pozo Moro y secuencia narrativa de sus relieves: algunas propuestas, Espacio, Tiempo y Forma, Serie II, Historia Antigua, 13, 325-356.

PRIETO, I., 2002: Nuevos elementos de discusión en torno al mundo funerario ibérico albacetense, II Congreso de Historia de Albacete, 185-187.

ROUILLARD, P. 1991: Les Grecs et la Péninsule Ibérique du VIIIe au IVe siècle avant JésusChrist (Paris). 
RUIZ, A.; MOLINOS, M. 1999: The Archaeology of the Iberians, Cambridge University Press.

RUIZ, A.; MOLINOS, M.; GUTIÉRREZ, L.Ma. \& BELLÓN, J.P. 2001: El modelo político del pago en el Alto Guadalquivir (s. IV-III a.n.e.), in Territori polític i territori rural durant l'edat del Ferro a la Mediterránea Occidental. Monografies d'Ullastret 2. Girona, 11-22.

SANZ, R., 1997: Cultura ibérica y romanización en tierras de Albacete: los siglos de transición, Instituto de Estudios Albacetenses, Albacete.

SANZ, R. (2006): "Un nuevo espacio histórico: el proceso de romanización en Castilla-La Mancha", Fuentes Domínguez, A., coord.: Castilla-La Mancha en época romana y Antiguëdad Tardía, Biblioteca Añil, 27. Almud. Ciudad Real: 53-96.

SILLIERES, P. 1990: Les voies de communication de l'Hispanie Méridionale, Publications du centre Pierre Paris, De Boccard (Paris).

SORIA, L. 2000: La cultura ibérica en la provincia de Albacete. Génesis y evolución a través del estudio del poblamiento. Tesis doctorales, Univ. Castilla-La Mancha.

SORIA, L. 2002: La estructuración del territorio albacetense durante el ibérico pleno (ss. VIII a.C.). Los grandes asentamientos y su distribución en el espacio. II Congreso de Historia de Albacete. Albacete. I. Arqueología y Prehistoria: 137-144.

VALERO, M.A., 2005: El mosaico de Cerro Gil: Iniesta, Cuenca, in Jiménez, J., Celestino, S. (coords.), El período orientalizante: Actas del III Simposio Internacional de Arqueología de Mérida, vol. 1, 619-634.

VAN DOMMELEN, P. 2006: The orientalizing phenomenon: hybridity and material culture in the western Mediterranean. In C. Riva and N. Vella (eds.) Debating Orientalization: Multidisciplinary Approaches to Change in the Ancient Mediterranean, 135-152 (London).

\section{CAPTIONS OF ILLUSTRATIONS}

Fig. 1. Geographical distribution of the Iberian peoples.

Fig. 2. Pozo Moro (Albacete, Spain), according to the current reconstruction in the National Archaeological Museum (Madrid).

Fig. 3. Reliefs of the monument of Pozo Moro.

Fig. 4. Location of the area of study in the Spanish Central Plateau.

Fig. 5. Settlement area at Cerro Gil and landscape between the necropolis and the settlement.

Fig. 6. Area of the necropolis of Cerro Gil (Cuenca)

Fig. 7. Location of the settlement and necropolis in Cerro Gil and its coincidence with the water wells identified in the cartography of 1942 . (C) Sig pac.

Fig. 8. Process of excavation of burial ground 1026 in Cerro Gil, with the mosaic in situ. Below, bronze belt and painted urn from its grave goods.

Fig. 9. Mosaic from a burial mould of Cerro Gil, as shown today in the Museum of Iniesta 
(Cuenca).

Fig. 10. Bronze vase of Valdegamas (Badajoz). (C) Léxico de Iconografía Ibérica, CSIC.

Fig. 11. Cattle tracks that unite Pozo Moro and Cerro Gil. (C) Ministerio de Medio Ambiente, Spain.

Fig. 12. Cattle paths and traditional routes between Chinchilla and Pozo Moro, as represented in the maps of 1893 and 2004. (C) Instituto Geográfico Nacional, Spain.

Fig. 13. Reconstruction of the itinerary of route 31 of Antonine between Chinchilla/Saltigi y Cerro Gil/Iniesta. Elaborated from an image from Google Maps, Inc.

Fig. 14. Archaeological works of Pozo Moro in the 1970 s and part of the grave goods associated to the tomb excavated inside the monument.

Fig. 15. To the left, decoration of the paterae of Tivissa. In red, the winged being associated to sacrifice. To the right, the slaughterer of Bujalamé.

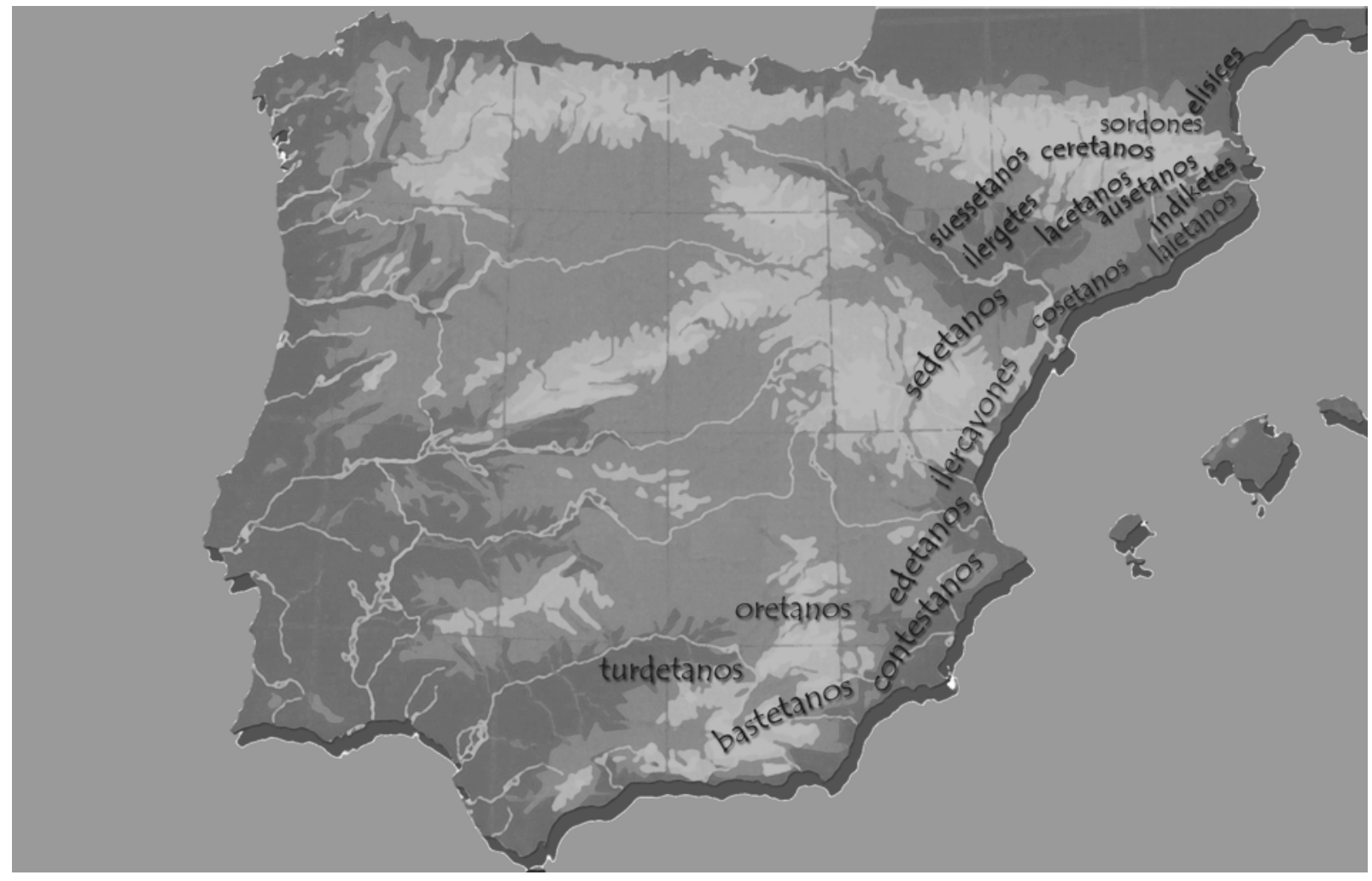

Fig. 1. Geographical distribution of the Iberian peoples. 


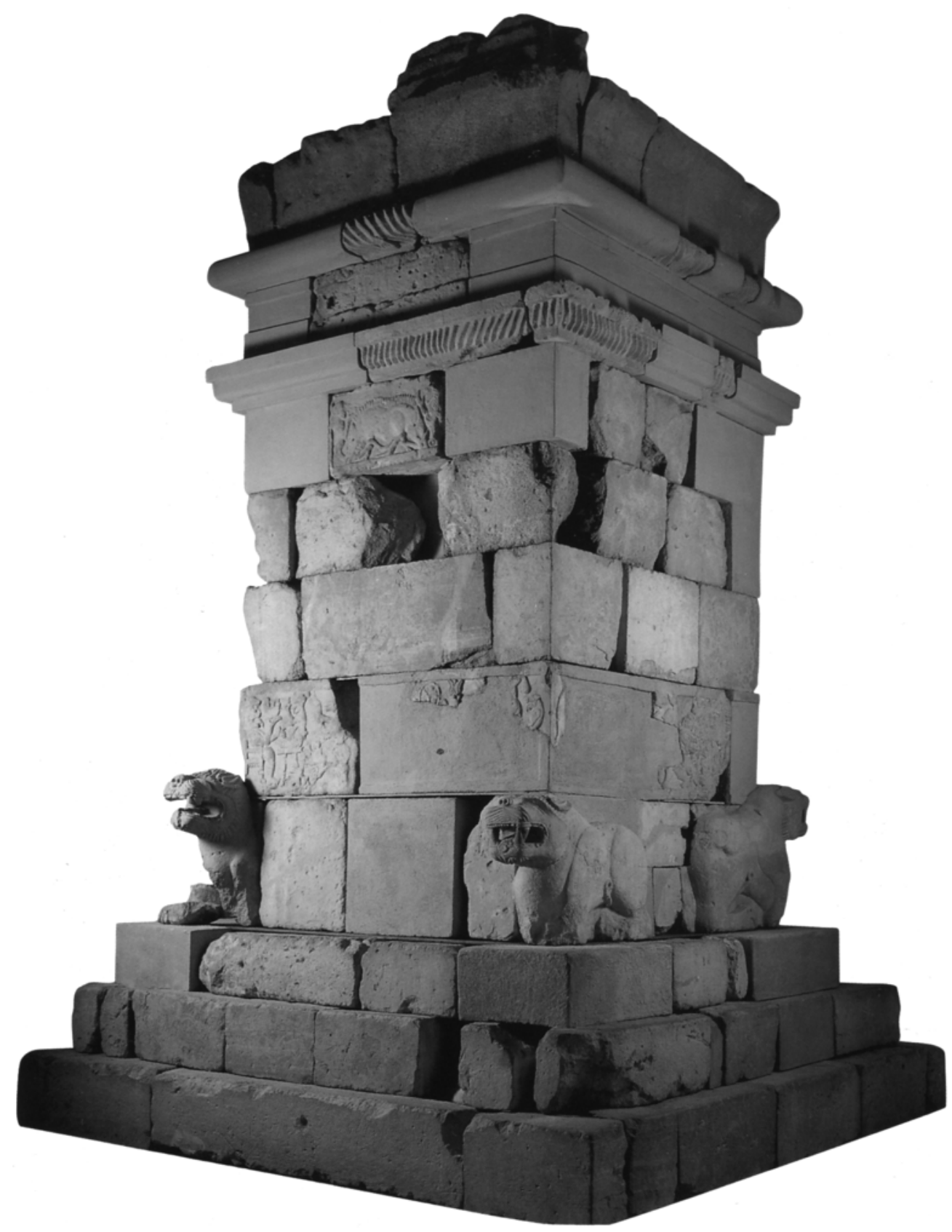

Fig. 2. Pozo Moro (Albacete, Spain), according to the current reconstruction in the National Archaeological Museum (Madrid). 

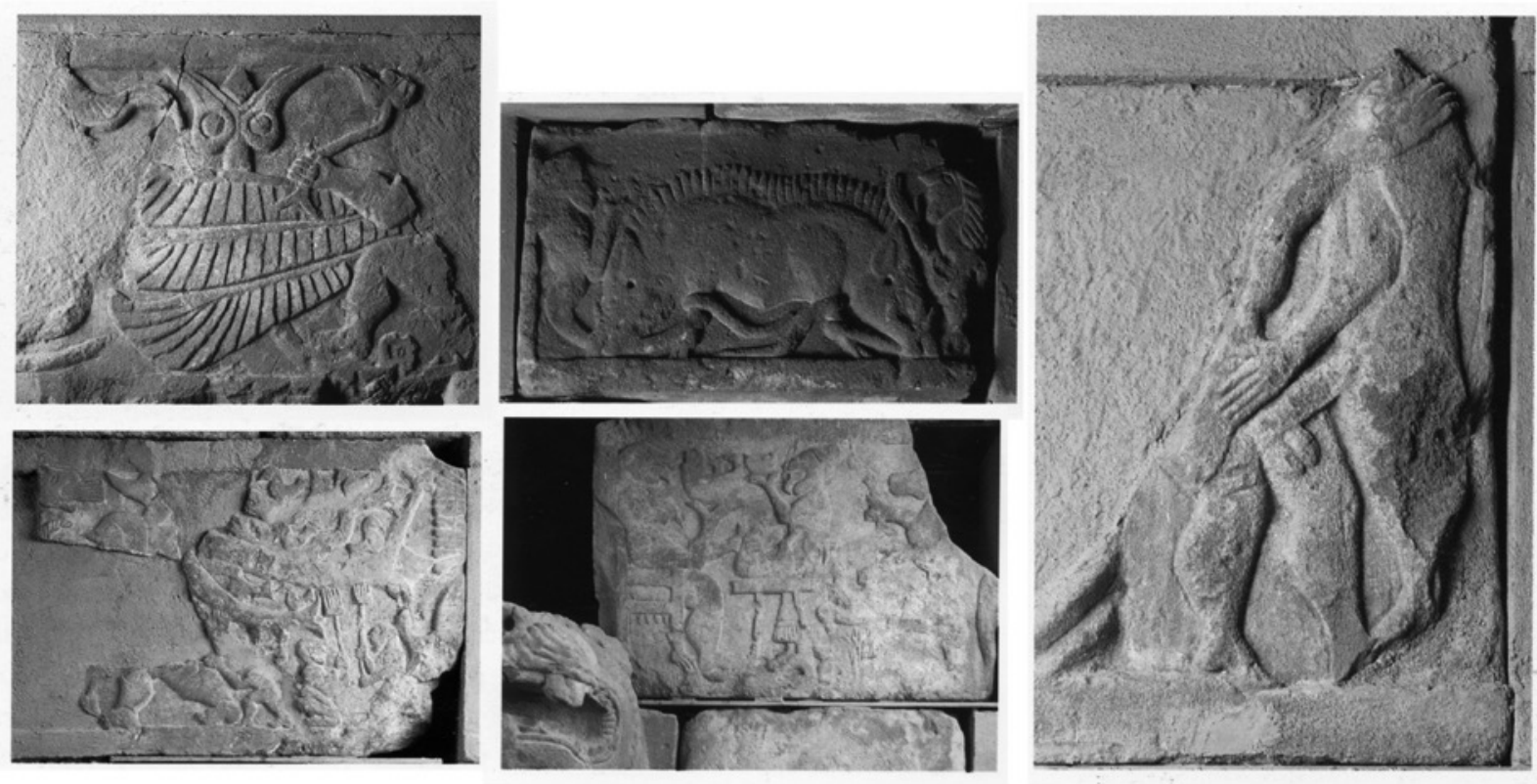

Fig. 3. Reliefs of the monument of Pozo Moro.

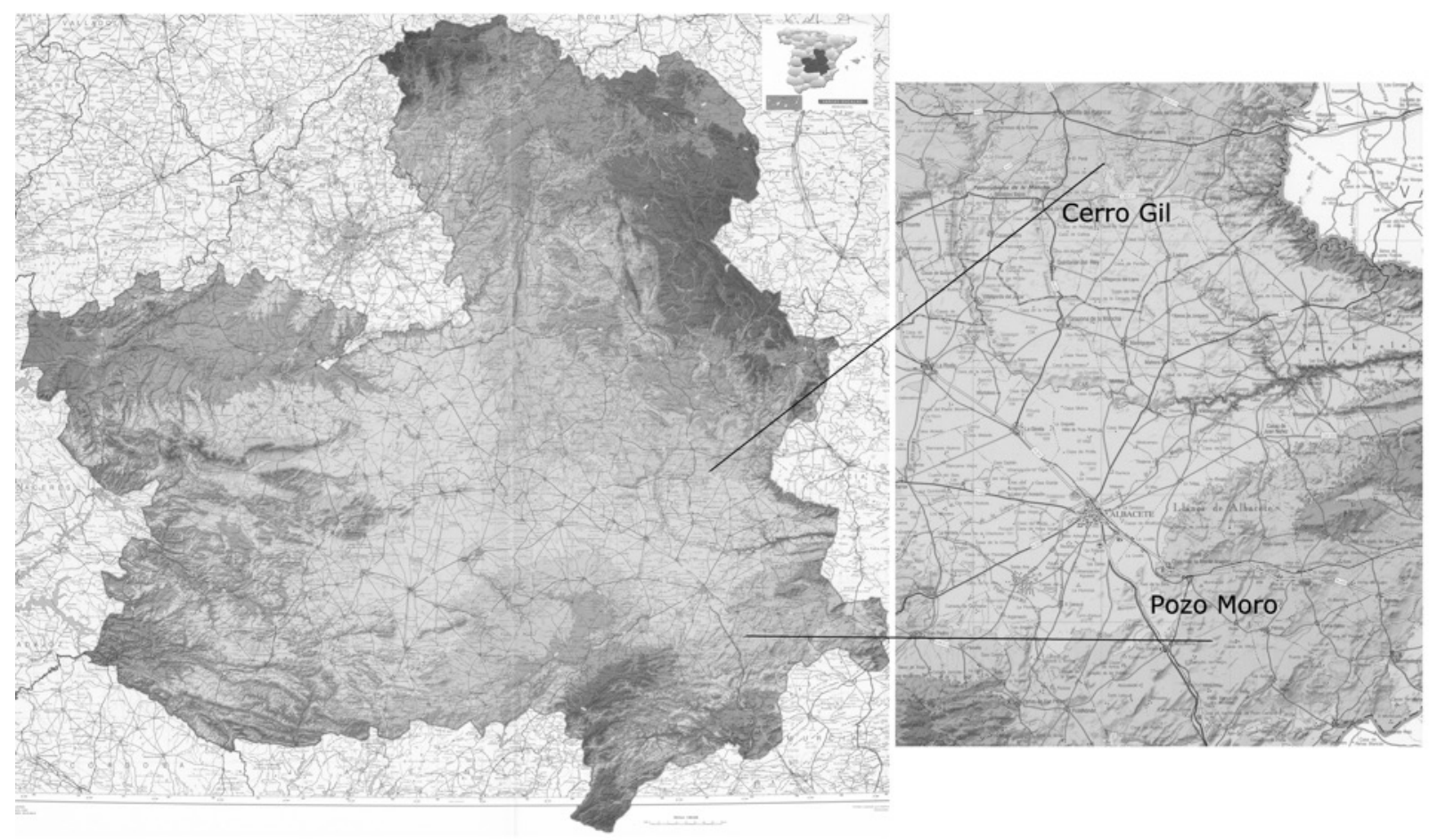

Fig. 4. Location of the area of study in the Spanish Central Plateau. 


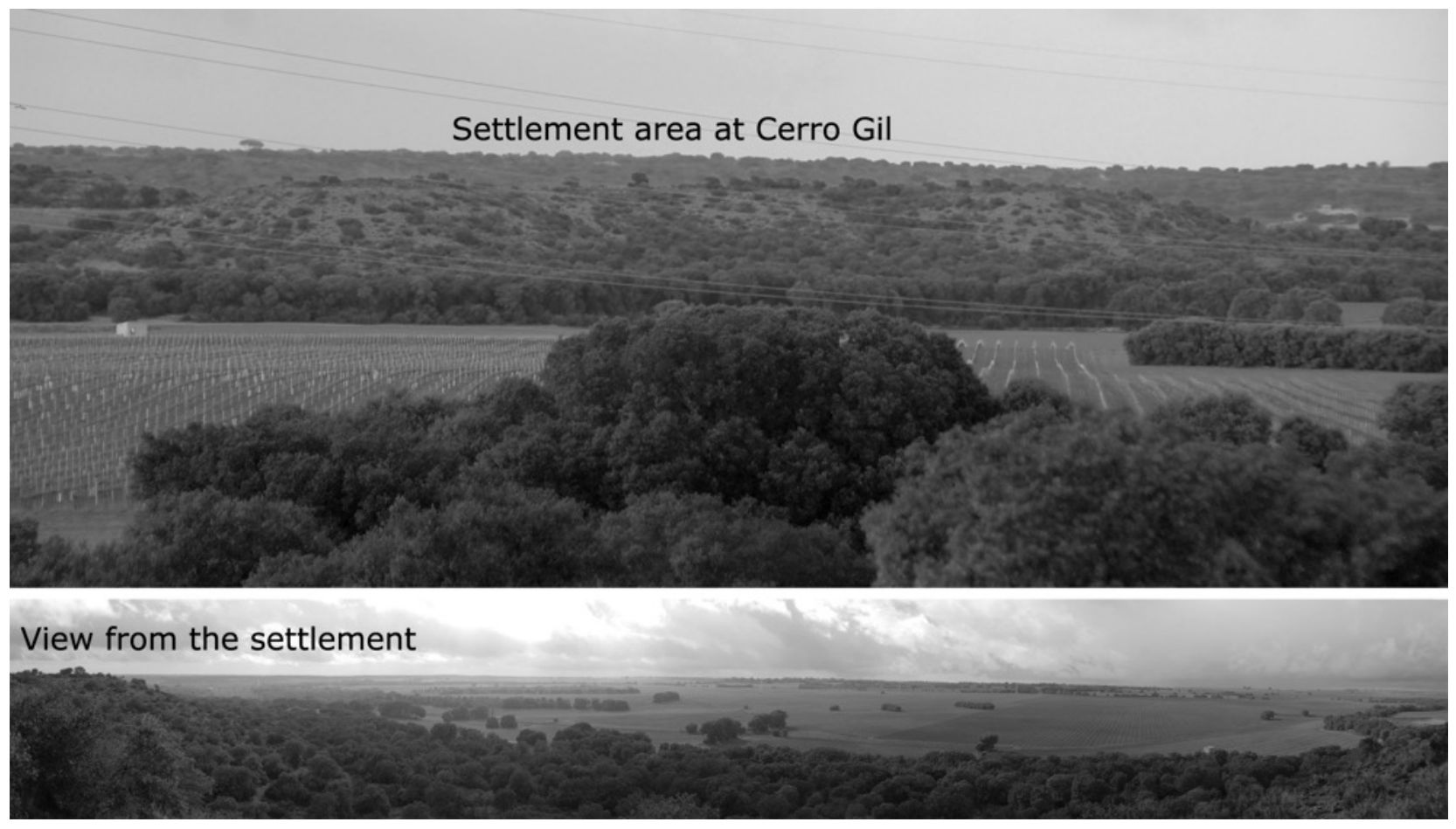

Fig. 5. Settlement area at Cerro Gil and landscape between the necropolis and the settlement. 

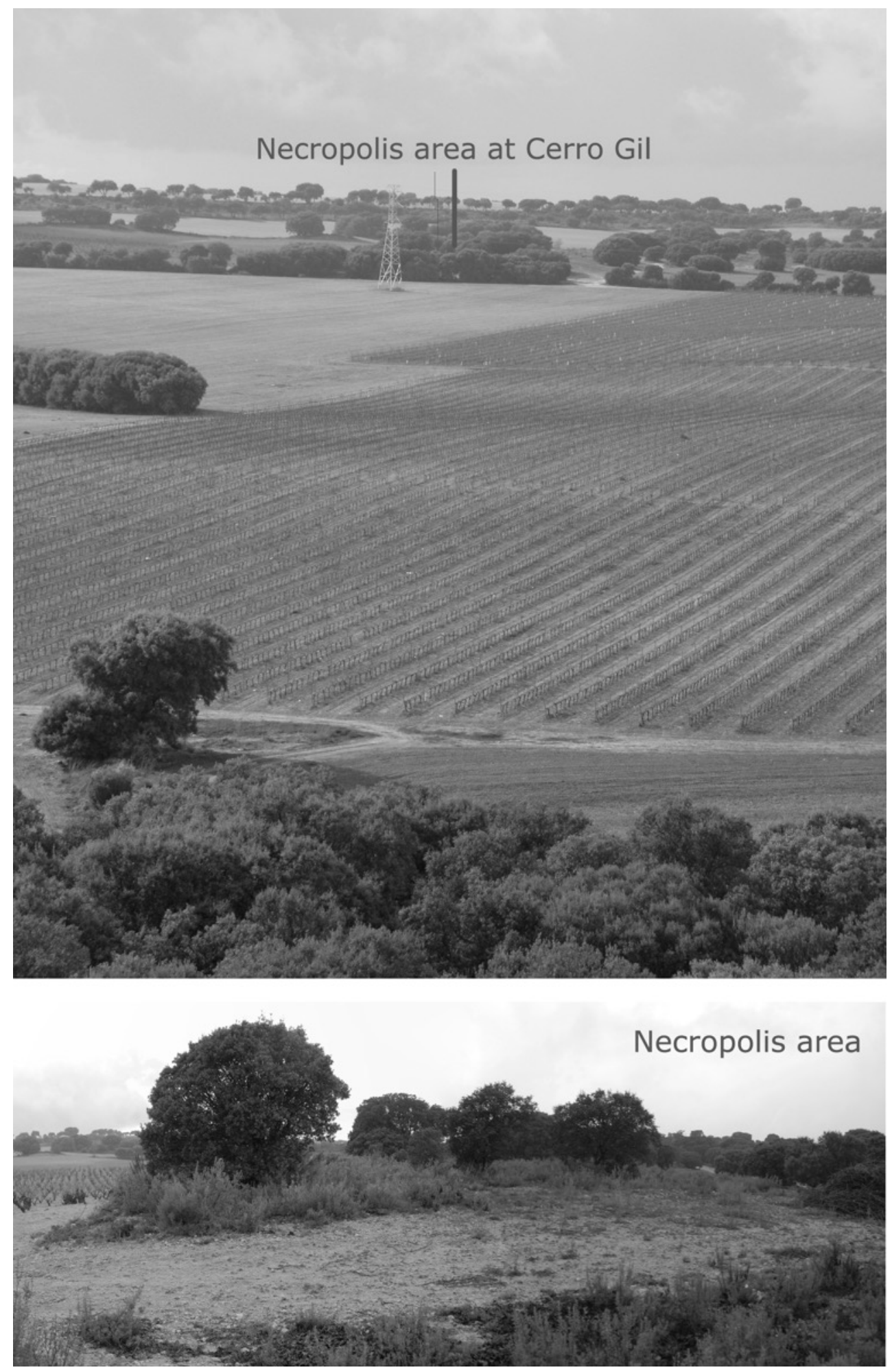

Fig. 6. Area of the necropolis of Cerro Gil (Cuenca) 


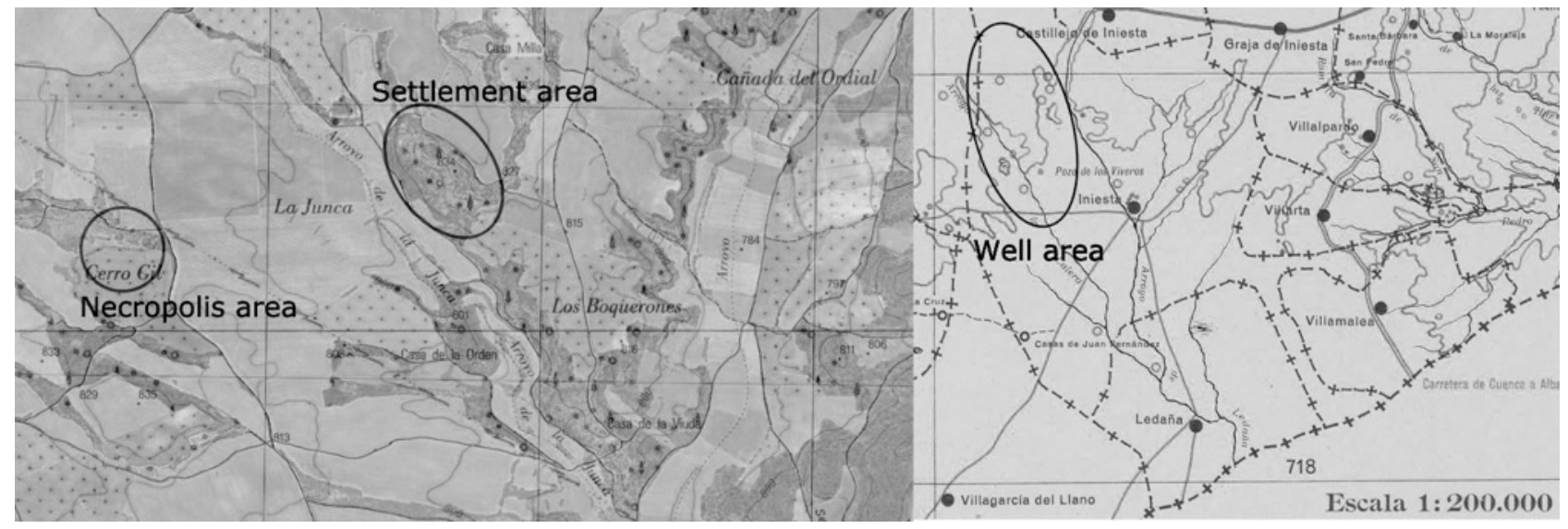

Fig. 7. Location of the settlement and necropolis in Cerro Gil and its coincidence with the water wells identified in the cartography of 1942 . (C) Sig pac.
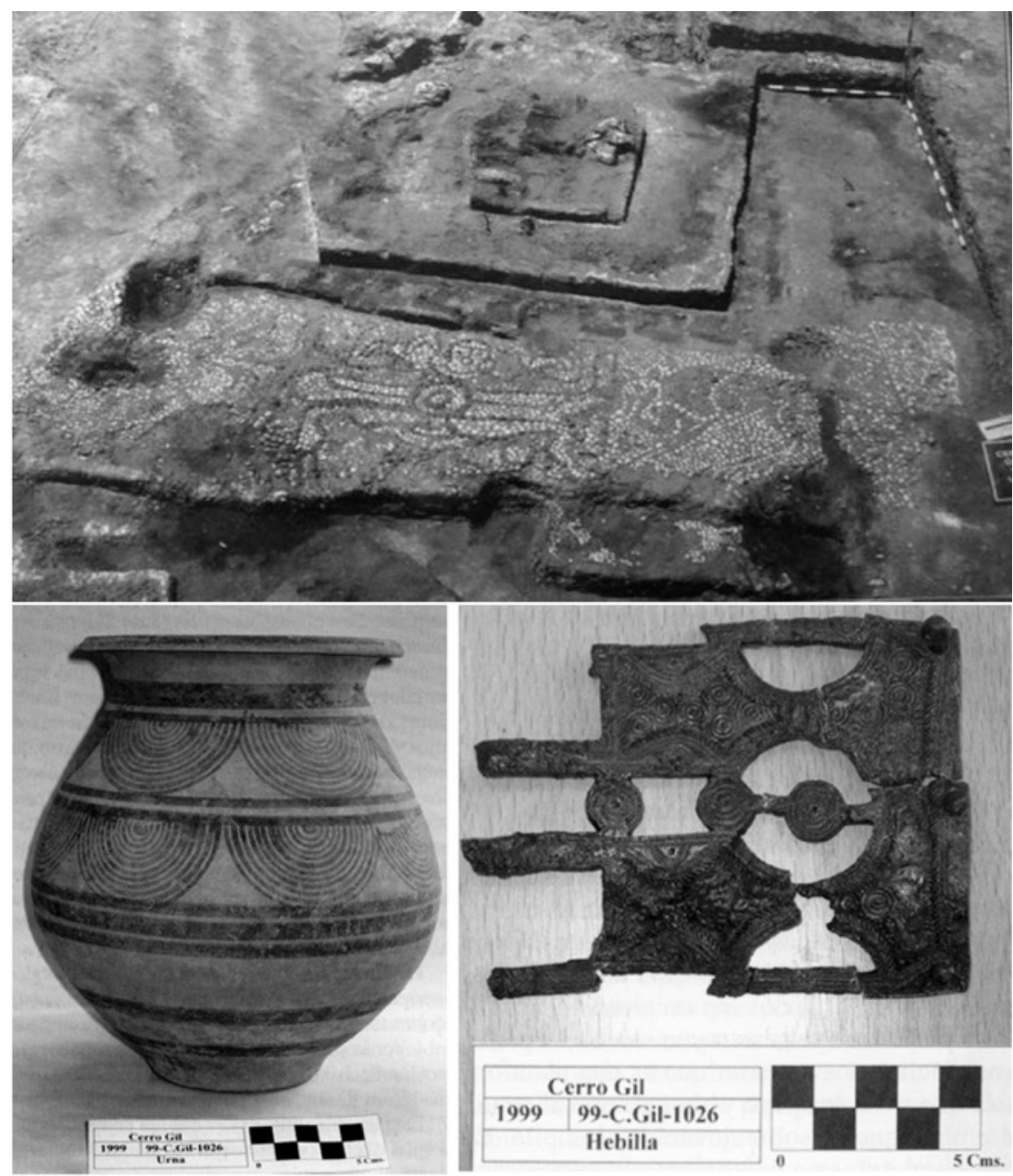

Fig. 8. Process of excavation of burial ground 1026 in Cerro Gil, with the mosaic in situ. Below, bronze belt and painted urn from its grave goods. 


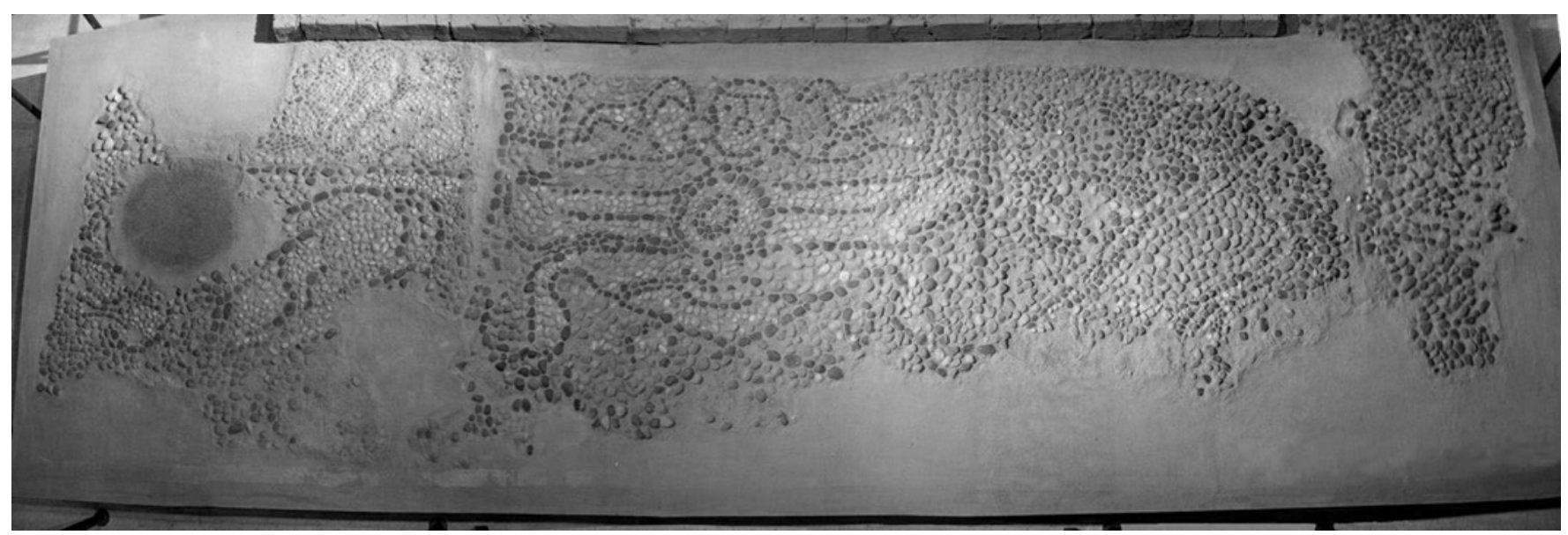

Fig. 9. Mosaic from a burial mould of Cerro Gil, as shown today in the Museum of Iniesta (Cuenca). 


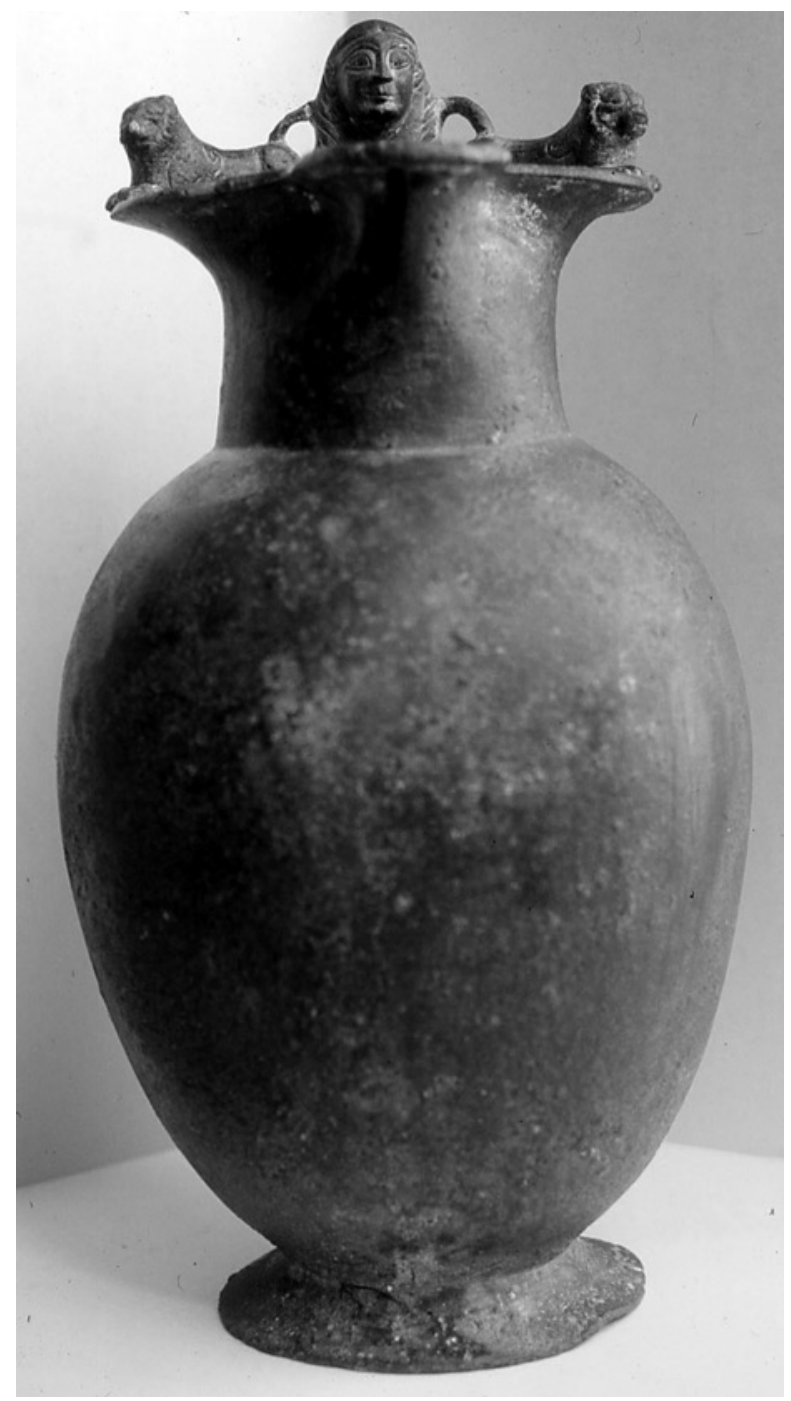

Fig. 10. Bronze vase of Valdegamas (Badajoz). (c) Léxico de Iconografía Ibérica, CSIC. 


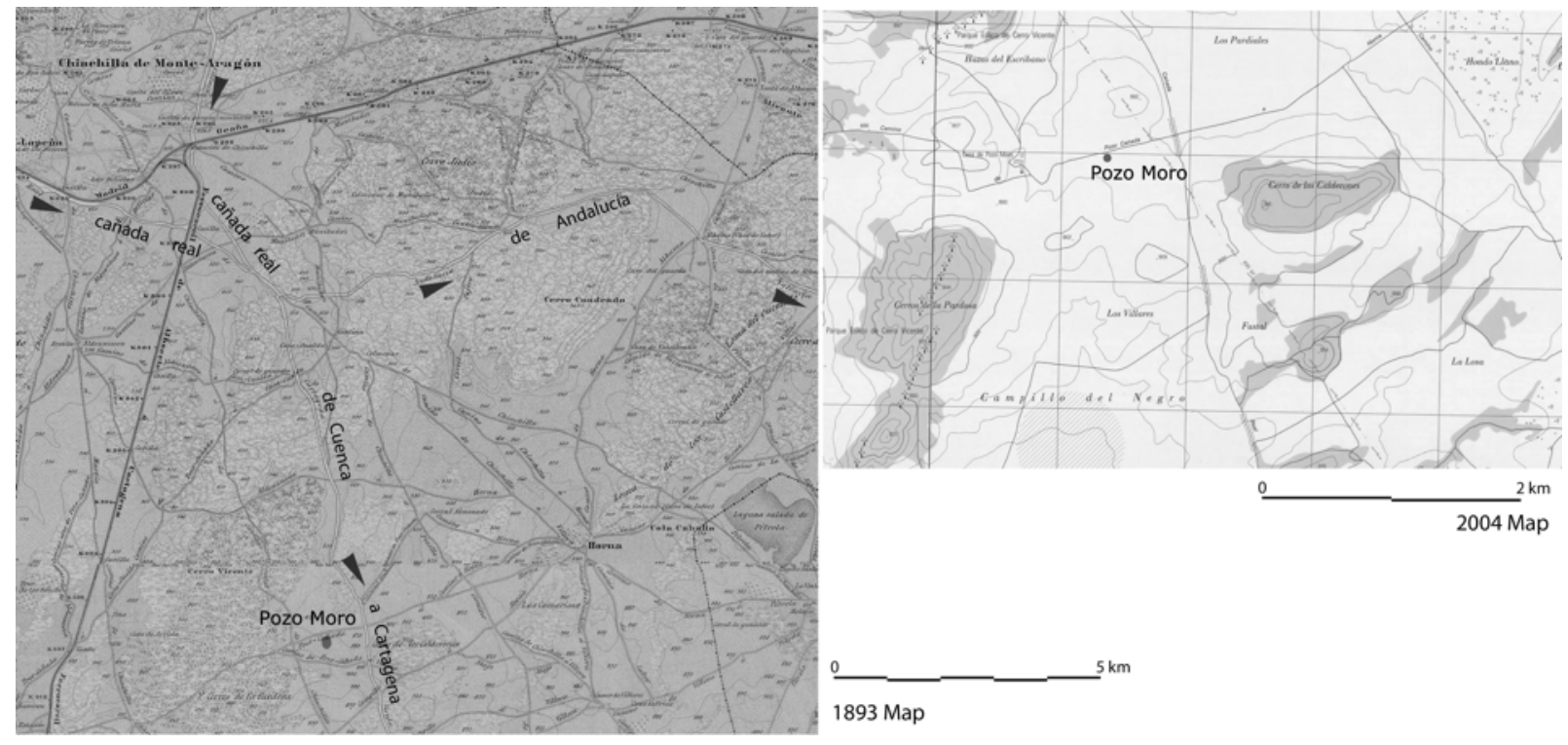

Fig. 11. Cattle tracks that unite Pozo Moro and Cerro Gil. (c) Ministerio de Medio Ambiente, Spain.

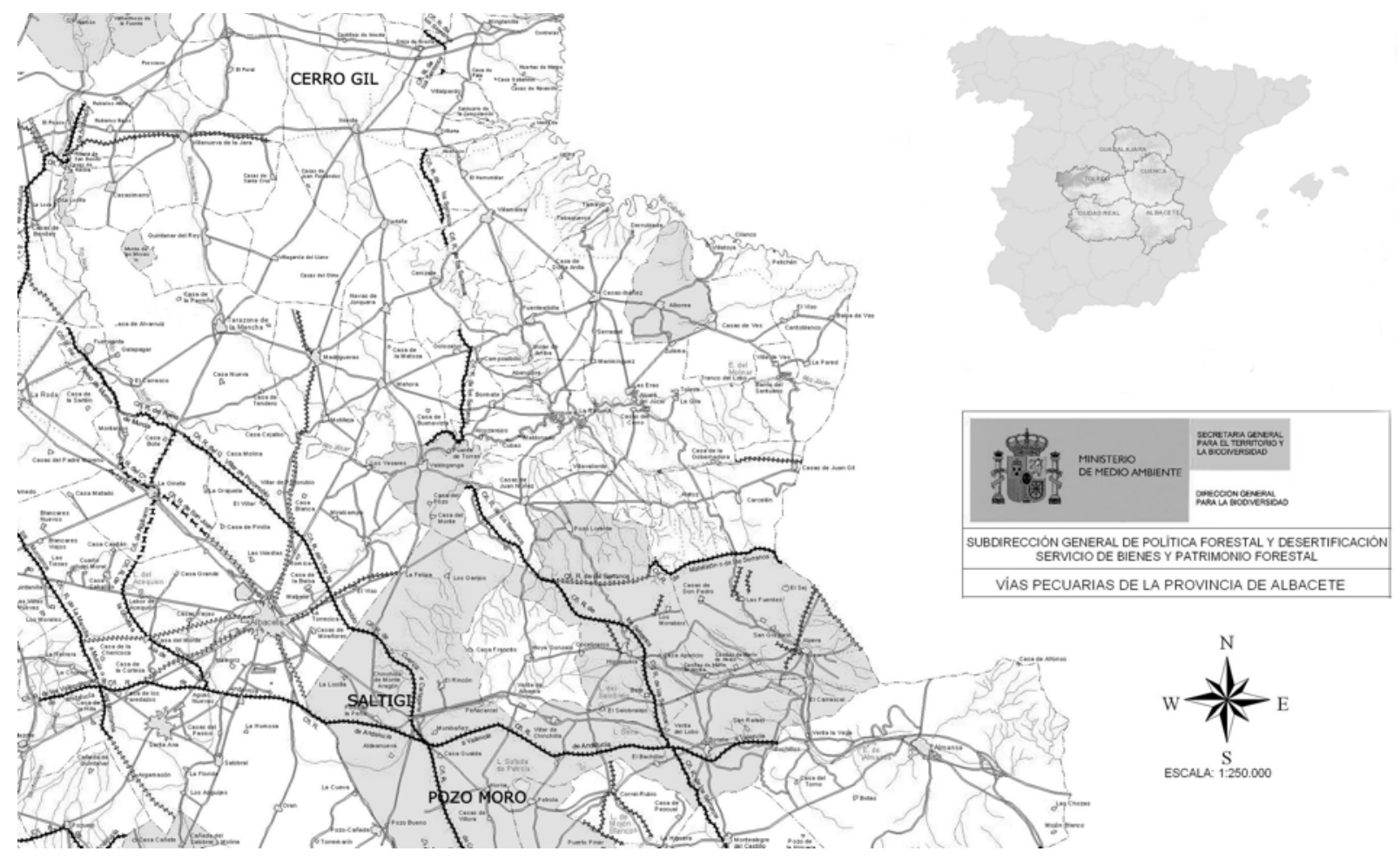

Fig. 12. Cattle paths and traditional routes between Chinchilla and Pozo Moro, as represented in the maps of 1893 and 2004. (C) Instituto Geográfico Nacional, Spain. 


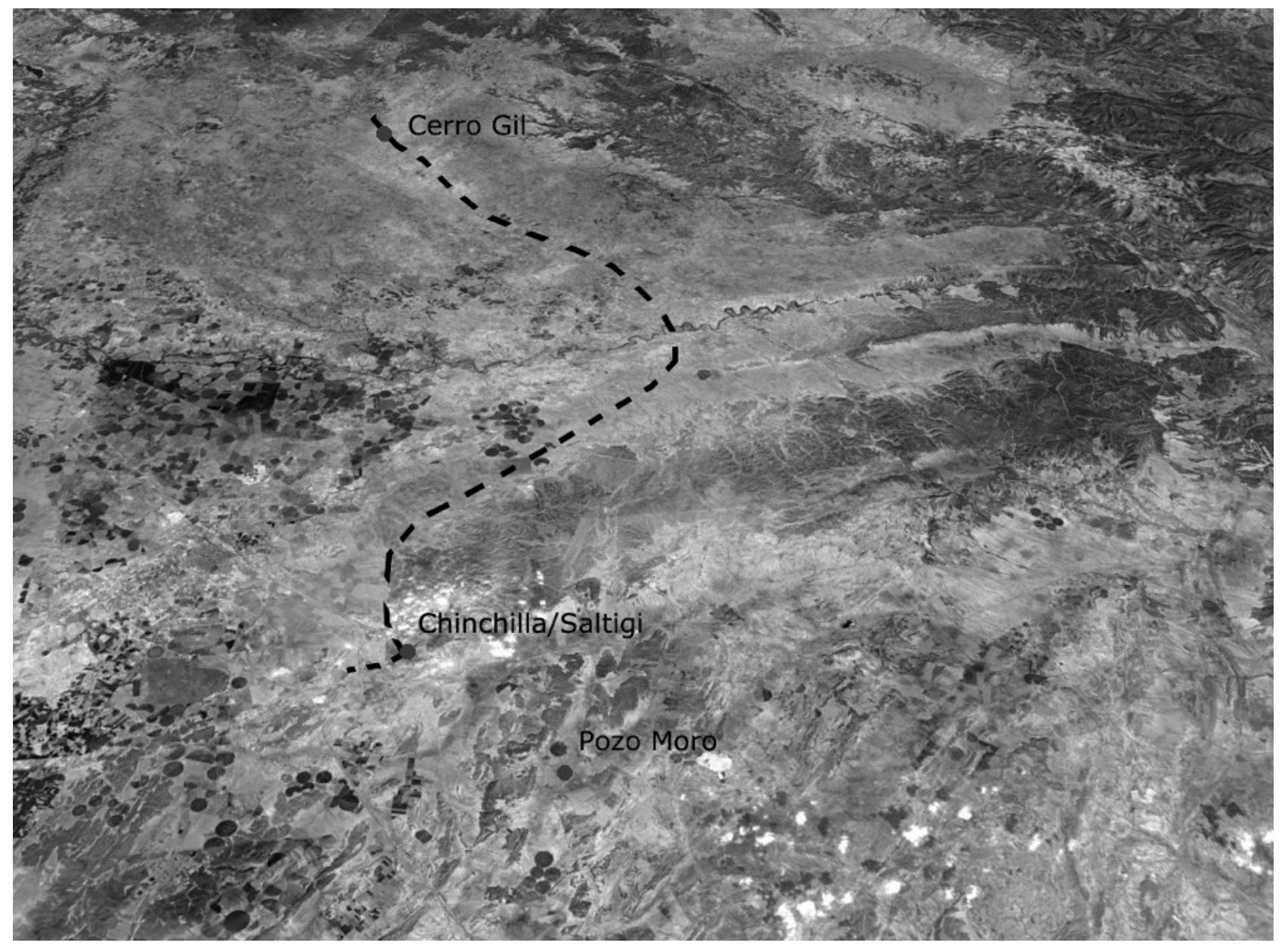

Fig. 13. Reconstruction of the itinerary of route 31 of Antonine between Chinchilla/Saltigi y Cerro Gil/Iniesta. Elaborated from an image from Google Maps, Inc. 


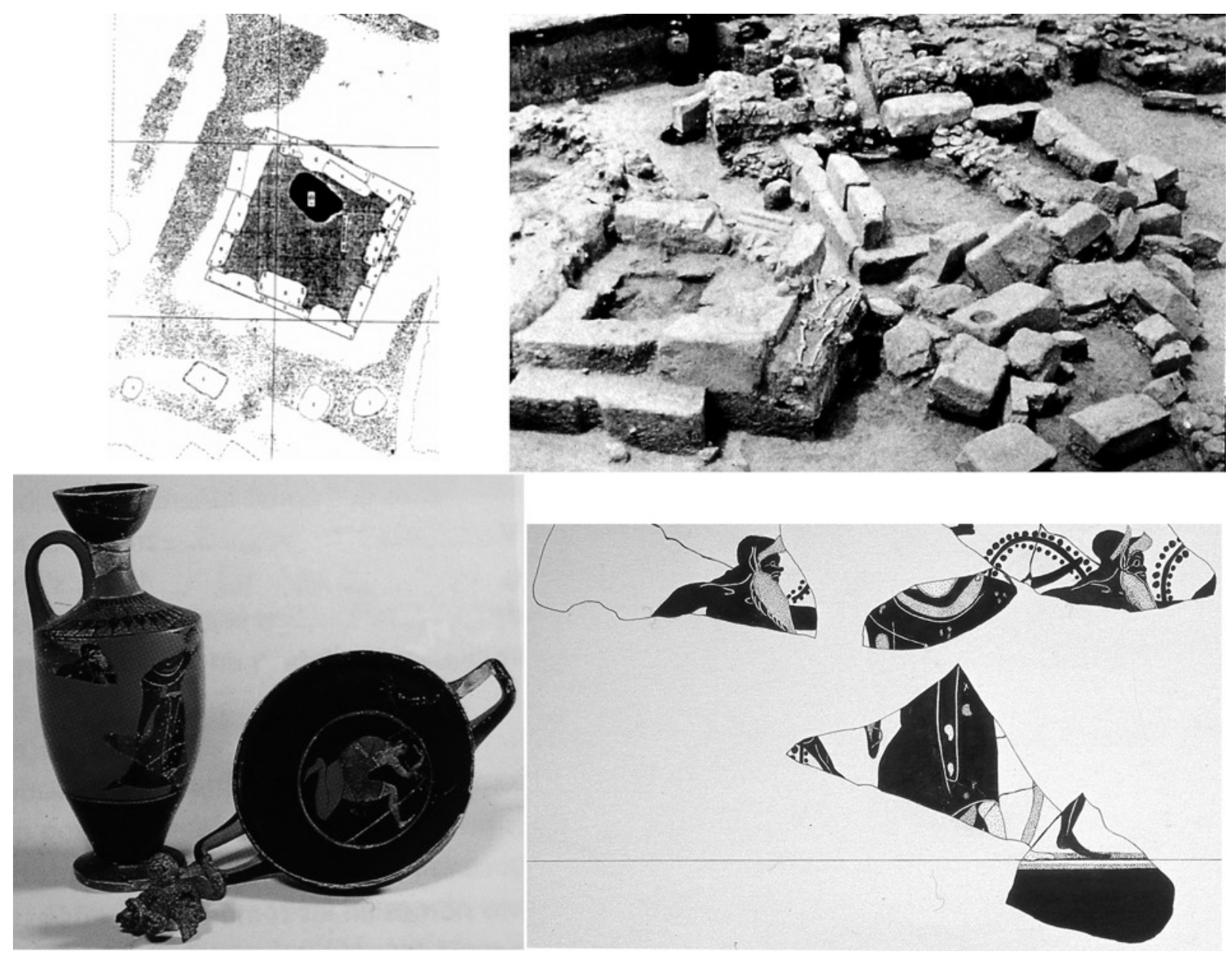

Fig. 14. Archaeological works of Pozo Moro in the 1970s and part of the grave goods associated to the tomb excavated inside the monument.
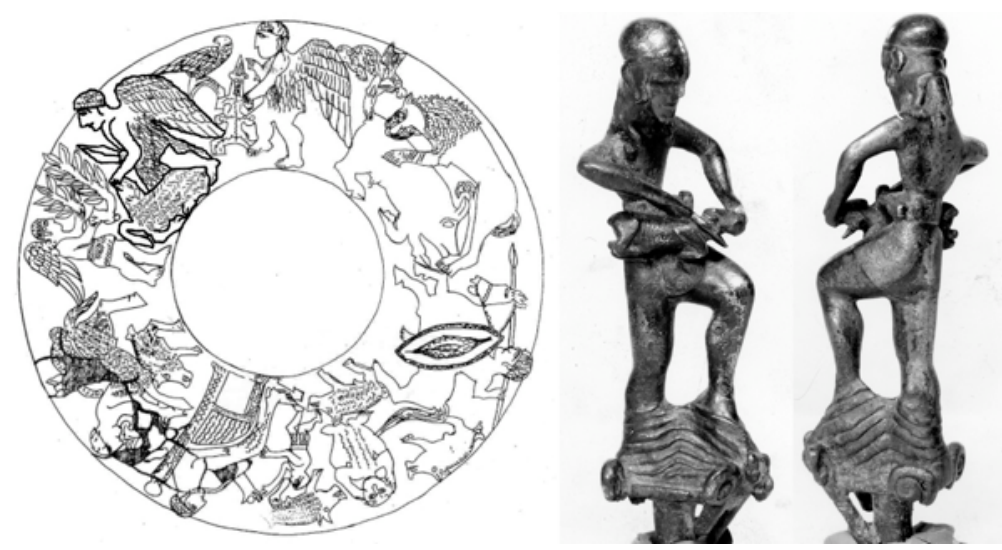

Fig. 15. To the left, decoration of the paterae of Tivissa. In red, the winged being associated to sacrifice. To the right, the slaughterer of Bujalamé. 